\title{
REGARDING THE ISSUE OF SPECIFICITY OF A. VVEDENSKY'S LANGUAGE
}

\author{
SOBRE A QUESTÃO DE ESPECIFICIDADE DA LINGUAGEM DE A.I. VVEDENSKY
}

SOBRE LA CUESTIÓN DE LA ESPECIFICIDAD DEL LENGUAJE DE A.I. VVEDENSKY

\author{
Liana Mikhailovna AKHMETZYANOVA ${ }^{1}$ \\ Ekaterina Gennadievna SHTYRLINA ${ }^{2}$ \\ Yevgeniya Aleksandrovna ZHURAVLEVA ${ }^{3}$
}

\begin{abstract}
The object of analysis in the provided article is the language-game as a method of representing the author's vision. The content behind term "language-game" is revealed by an art space of A.I. Vvedensky, Russian poet of avant-gardism and philosopher. It is analyzed a distinction between children's and adult's works. The main content of the current study is an analysis of the most effective methods of language-game presentation in artistic communication of the poet, such as free verse, contamination of phraseological units, comparison, semantic indifference of lexemes, transformation of grammar categories, phrase deformation, etc. Based on the conducted research, a conclusion about specifics of the poet's individual writing style can be made. In Vvedensky's linguistic poetics, language-game manifests itself at different levels of text function as an important factor to text formation. It is important to note that language-game techniques found in his children's works are aimed at building a positive dialog and are seen as a positive phenomenon, while his more mature works feature an abstract artistic world with abstract artistic meaning.
\end{abstract}

KEYWORDS: World of contradiction. Words-hieroglyphs. Methods of language-game. Transformations.

RESUMO: O objeto de análise do artigo é o jogo de linguagem como método de representação da visão de autor. O conteúdo por trás do termo "jogo de linguagem" é o espaço de arte da A.I. Vvedensky, poeta russo de vanguarda e filósofo. É analisada a distinção entre obras infantis e adultas. O conteúdo principal do presente estudo é uma análise dos métodos mais eficazes de apresentação de jogos de linguagem na comunicação artística do poeta, tais como versos livres, contaminação de unidades fraseológicas, comparações, indiferença semântica de lexemas, transformação de categorias gramaticais, frase deformação, etc. Com base na pesquisa realizada, são feitas conclusões acerca das especificidades do estilo de escrita individual do poeta. Na poética linguística de Vvedensky, o jogo de linguagem se manifesta em

\footnotetext{
${ }^{1}$ Kazan Federal University (KPFU), Kazan - Russia. Associate Professor of the Department of Russian as a Foreign Language, Institute of Philology and Intercultural Communication. Candidate of Philology. ORCID: https://orcid.org/0000-0002-5124-2777. E-mail: lianaorx@rambler.ru

${ }^{2}$ Kazan Federal University (KPFU), Kazan - Russia. Associate Professor of the Department of Russian as a Foreign Language, Institute of Philology and Intercultural Communication. Candidate of Philology. ORCID: https://orcid.org/0000-0001-7112-3380.E-mail: shtyrlinaekaterina@gmail.com

${ }^{3}$ Gumilyov Eurasian National University (ENU), Astana - Kazakhstan. Professor and Head of the Department of Theoretical and Applied Linguistics. Doctor of Philology. ORCID: https://orcid.org/0000-0001-9566-8481. Email: zhuravleva_ea@enu.kz
} 
diferentes niveis de função do texto como um importante fator de formação do texto. É importante notar que as técnicas de jogos de linguagem encontradas na sua poesia para crianças visam construir um diálogo positivo e são vistas como um fenômeno positivo, enquanto suas obras mais maduras apresentam um mundo artístico abstrato com significado artístico abstrato.

PALAVRAS-CHAVE: Mundo de contradições. Palavras-hieróglifos. Métodos de jogo de linguagem. Transformações.

RESUMEN: El objeto de análisis en el artículo proporcionado es el juego de lenguaje como método de representación de la visión del autor. El contenido del término "juego de lenguaje" es revelado por el autor del artículo; un espacio de arte de A.I. Se analiza a Vvedensky, poeta ruso del vanguardismo y filósofo, y se hace una distinción entre obra infantil y obra de adultos. El contenido principal del presente estudio es un análisis de los métodos más efectivos de presentación de juegos de lenguaje en la comunicación artística del poeta, tales como verso libre, contaminación de unidades fraseológicas, comparación, indiferencia semántica de lexemas, transformación de categorías gramaticales, frase deformación, etc. Sobre la base de la investigación realizada, se puede llegar a una conclusión sobre los aspectos especificos del estilo de escritura individual del poeta. En la poética lingüistica de Vvedensky, el juego de lenguaje se manifiesta en diferentes niveles de función del texto como un factor importante de formación del texto. Es importante señalar que las técnicas de juegos de lenguaje que se encuentran en las obras de sus hijos tienen como objetivo construir un diálogo positivo y se ven como un fenómeno positivo, mientras que sus obras más maduras presentan un mundo artístico abstracto con un significado artístico abstracto.

PALABRAS CLAVE: Mundo de contradicciones. Jeroglíficos de palavras. Métodos de juego de linguaje. Transformaciones.

\section{Introduction}

Any author's text, especially works of fiction, can be considered representative of author's language that needs to be treated not simply as an individual manner of expressing themselves, but also as a language that reflects certain linguocultural timeline. Due to that, an interest of modern linguistics field about fiction language seems logical. Thus, modern linguistic researches dedicated to the analysis of writing style are characterized by the diversity of their theoretical orientations and points of view about problems of text analysis and its units (SPIRIDONNOV; KHABIBULLINA, 2016; SAFIN; KOLOSOVA; GIMRANOVA, 2017; STAROSTINA; BOCHINA; LARIONOVA, 2017; EROFEEVA; GIMATOVA; SERGEEVA, 2018; SHTYRLINA; ANTROPOVA, 2018; BIDERKESEN; AGEEVA; SEVINC, 2019). By referencing linguistic features of works, their meaning and their role in individual and general language unit organization become apparent. 
Personality of Alexander Ivanovich Vvedensky (1904-1941) has and has been attracting attention at least due to the fact that Vvedensky had been one of the founders (along with D. Kharms) of literature and theatrical group OBERIU (Ob"edinenie real'nogo iskusstva, the Union of Real Art). Members of OBERIU had created not only a new area of prose and poetry, but also a unique style of thought and life. Such terms as absurdity and zaum ("transreason", "beyondsense") play an important role in their art. Thus, poetic or prosaic work is interpreted as an instrument for language-game, buffoonery and jokes, while fictional world created by them transforms into a platform for performing purely formal exercises using different literature and linguistic methods. Vvedensky has referred to himself as "a nonsense authority", believing that the true logic of being is concluded in a nonsense; that only absurdity can express incoherency of life and death in constantly changing space and time.

\section{Methodology}

Specificity of the analyzed material has led to the usage of descriptive and interpretative methods, as well as the techniques of stylistic analysis of the text.

\section{Results and discussion}

To discover the correct types of connection on text level, Vvedensky resorts to the use of unique artistic symbol-hieroglyphs (term was firstly used by L. Lipavsky). Hieroglyph is something that "cannot be heard by ears, seen by eyes and understand by mind" (DRUSKIN, 2000). For example, a word "sea" in Vvedensky's works, on the one hand, saves its symbol nature and, on the other hand, represents border between living world and the world of dead, a space of alternate reality; it ceases to act only as a symbol and its meaning is enhanced - thus, this word becomes a hieroglyph. This word-hieroglyph allows semantic polyfunctionality when it is possible to suggest one's own poetic concepts. One of the main features of such hieroglyph is its absurdity, irrationality. Words-hieroglyphs are the base of Vvedensky's "nonsence" poetry. One of the methods of nonsense realization is language-game.

The term "language-game" was created by Austrian philosopher and logician Ludwig Wittgenstein (1889-1951). As author described it, language-game is the foundation that, as a form of life, defies further explanation and analysis, which is why any human activity (both spoken and sometimes unspoken) is simply a set of language-games: "I will call a languagegame the whole that consists of language and those types of activity with which it is bound" 
(WITTGENSTEIN, 1994). Currently, the term "language-game" is considered in two key meanings: broader, philosophical one (as author intended), and the more narrow, linguistic one.

There is a great amount of works in linguistics that analyze the different aspects of language-play (works of A. Wierzbicka, V.V. Vinogradov, E.A. Zemskaya, E.B. Lebedeva, T.A. Gridina, B. Yu. Norman, V. Z. Sannikov etc.). In linguists' scientific jargon, the term "language-game" includes all "events when the speaking person "plays" with the speech form, when the loose use of speech forms receives an aesthetic task, even the humblest one" (ZEMSKAYA; KITAJGORODSKAYA; ROZANOVA, 1983). In opinion of T.A. Gridina, the point of language-game is to purposefully use the norm derivative language structures: "Language-game creates different from the usus and norm means of expressing certain contents or objectifies new content while saving or modifying the old form" (GRIDINA, 1996). In other words, language-game blurs the line between codified literature language and colloquial speech. As noted by N.A. Nikolina and E.A. Ageeva, language-game "assumes the language system (and system of its usage) as a premise for realization of all kinds of derivations, derivation from the "correct" (familiar, communicatively conditioned) construction of language and functioning speech units" (NIKOLINA; AGEEVA, 2000).

In modern linguistics, a term "language experiment" is considered synonymous to the language-game (V.Z. Sannikova, E.P. Lavrik, J. Huizinga etc.).

In the 30's, where ideological repressions had been rampant in Soviet Union, the only published works of OBERIU members were children's works. Expressive, rich, occasionally paradox fantasy of writers introduces young readers to the magical world of game, happiness and joy.

It is important to note that children's and adult's works of Vvedensky are related to each other. The relation was direct - in a unique rhythm and text organization - and contrast: from kind, full of life and light typical for children's poems and stories world, author changes the direction to the never-ending chaos of adult works world which are full of tragedy and fear.

During his lifetime, A. Vvedensky was published as a children's poet.Vvedensky's poetry addressed to the children is playful, joyful, clear, easy to memorize, it rhymes well. It is as if author is talking with a child in a simple, colloquial manner:

Ya po sadiku gulyayu,

ya cvetochki sobirayu,

ya na yablonyu vlezayu,

v nebo yabloki brosayu, 
v nebo yabloki brosayu

naudachu, na avos',

pryamo v nebo popadayu,

pryamo v oblako naskvoz'.

Nadoelo mne brosat'sya,

zahotelos' pokupat'sya,

bul'

bul'

bul'

bul'

zahotelos' pokupat'sya [Uzh ya begal, begal, begal].

Original rhythm of poet's verses is based on the repetition of sounds and words. It can be a nursery rhyme:

Dozhdik, dozhdik,

Glyan', glyan'!

Dozhdik, dozhdik,

Gryan', gryan'!

ZHdut tebya $v$ sadu cvety,

Dozhdik, dozhdik,

Gde zhe ty?

Zhdut polya,

I zhdut berezy,

Topolya,

Duby i rozy,

Nezabudki

I byki,

Kury, utki,

Indyuki [Pesenka o dozhde].

Rain is portraited as a living creature, with which a child comes into contact. Emotions of happiness, trust, belief in a good are built in the poetry's system - with repetitions, rhythm and sound of every word. This nursery rhyme creates the belief in word significance to a child. 
Such sound and rhythm game can be seen in the "Pesenka pro loshadku" [Song about a horsey], where, for example, with the help of continuous use of sounds $\partial$ and $m$ the clopping sound is imitated. Author consciously uses such sound play to create certain impression in reader's mind. Such method is called "onomatopoeia", or "sound imitation":

\author{
Zhila-byla loshadka, \\ Zhila-byla loshadka, \\ Zhila-byla loshadka, \\ A u loshadki hvost, \\ Korichnevye ushki, \\ Korichnevye nozhki. \\ Vot vyshli dve starushki, \\ Pohlopali v ladoshki, \\ Zakladyvali drozhki \\ I mchalis' po dorozhke... [Loshadka].
}

In turn, verse from the poem "Kolybel'naya" [Lullaby] reminds us of some magical spells:

Ya sejchas nachnu schitat':

Raz, dva, tri, chetyre, pyat'.

Tol'ko konchu ya schitat':

Vse davajte spat'! spat'!

Po dorogam hodit son,

Raz, dva, tri, chetyre, pyat'.

Vsem prikazyvaet on:

Spat'. Spat'. Spat'. Spat'.

Son po ulice pojdyot,

A emu navstrechu kot.

Kot usami shevelit.

Son kotu usnut' velit.

Raz, dva, tri, chetyre, pyat'.

Spat'. Spat'. Spat'. Spat' [Kolybel'naya]. 
As we can see, plots of children's books are quite simple. The main author's objective is to create comical effect. At the same time, a playful discourse is primarily targeted at a cocreation and thinking development.

Vvedensky eagerly experiences with artistic forms in his adult works either. His most favorite artistic form was vers libre - the free verse:

\author{
Mne strashno chto ya dvigayus' \\ ne tak kak zhuki zhuki, \\ kak babochki i kolyaski \\ i kak zhuki pauki. \\ Mne strashno chto ya dvigayus' \\ nepohozhe na chervyaka, \\ chervyak proryvaet $v$ zemle nory, \\ zavodya s zemlej razgovory. \\ Zemlya gde tvoi dela, \\ govorit ej holodnyj chervyak, \\ a zemlya rasporyazhayas' pokojnikami, \\ mozhet byt' $v$ otvet molchit, \\ ona znaet chto vse ne tak... [Mne zhalko, chto ya ne zver'...].
}

It is a conscious author's decision to derive from the rhythm. Such combination of correct verse measure and free verses gives off weird, but at the same time smile-making mood. Rhythm and sound structure of Vvedensky's texts is contracted by the texts' semantics, one of the language-game methods.

A specific method of language-game realization in the "nonsense" poetry of Vvedensky is the method of children's speech error, the point of which is to play out typical features of children's speech: replacement of word with paronym, contamination of phraseological units ("vremya obedennoe idti domoj" (Beseda chasov), "tureckij brat na pomoshch' stoit" (Minin i Pozharskij)), errors in verb management ("Ya tiho vyshel za drova" (Fakt, teoriya i Bog)), subordinate part collapsing in complex sentences, contamination of several phrases ("Ya sidel i ya poshel kak rastenie na stol... na sobran'e mirovoe" [Gost' na kone], "Chto ty znachish' ili net” [Znachenie moray], “Kuda umresh" [Fakt, teoriya i Bog]) (VALIEVA, 2016).

One of the most effective ways of language-game realization is the comparison ("chasy idut... kak osetrovyj hryashch" [Lesoruby]; "tolpa kak London zarychala" [Krugom 
vozmozhno Bog]; "voskhodit svetlyj komissar kak yablok nad lyud'mi” [Vse]; "i pyatachkom glaza zakryv // lezhal kak pal'ma // byl krasiv", "ty okonchish' put', rygaya, kak pal'my i loto" [Svyatoj i ego podchinennye] etc.). An absolute discrepancy of characteristics is seen in combinations of verb predicates with adverbs or names. In a broader sense, objects and events are compared that have no similar features:

dve ptichki kak odna sova

leteli nad shirokim morem

i razgovarivali o sebe

nu prosto kak sluchajnye indejcy... [Dve ptichki, gore, lev i noch'].

uvy stoyal plachevnyj stul

sidel aul na

nem sidel bol'shoj bol'noj

sidel k zhivushchemu spinoj... [Bol'noj kotoryj stal volnoj].

VISYASHCHIE LYUDI.

Bozhe my razveshany,

Bozhe my pomeshany,

my na dereve na stule tom visim,

v dudku golosa svistim,

shashkoj mashem vpravo vlevo

kak sunduk i koroleva [Mir].

The next feature of "nonsense" poetry of Vvedensky is the semantic indifference of words, both with the category grade (specificity/abstractness, animate/inanimate, singularity/multiplicity etc.) and with common and individual names: Bogu molyatsya neslyshno more, los', kuvshin, gumno, svechka, vsadnik, chelovek, lozhka i Hadzhi-Abrek ("Krugom vozmozhno Bog"); moh i botichelli (“Ostrizhen skopom Rostislav"); ten' divan tatary lun' pavlin uzh letyat stepnye galki ("Nachalo poemy"). Name as a concept loses its distinctive and classification features.

While researching space of Vvedensky's works, such an important component of language-game as transformation of grammar categories should not be ignored: pasekoj ikaet; sneg na rosu nachal nos puskat' (“Ostrizhen skopom Rostislav”); obratnyj boj kladet; sadyatsya na pristupku porhaya semero vdvoem ("Vospitanie dushi"); spyat enoty chereschur ("Minin i Pozharskij”), as well as their phraseological phrases: $i$ u neba u dorozhki svesiv pristal'nye 
rozhki ("Svyatoj i ego podchinennye") (svesiv nozhki i vystaviv rozhki); zubom mudrosti stuchit (“Znachenie moray”) (zub mudrosti i stuchat' zubami); gus' do etogo molchal tol'ko cherepom kachal (“Otvet bogov”) (kachat' golovoj); komar zdes' peshih ne podtochit ("Parsha na otmeli”) (komar nosa ne podtochit) etc. Such transformations and deformations are meant to help reader form their own poetic concepts and interpret text their own way.

\section{Summary}

The conducted linguistic stylistic analysis of A. Vvedensky's works provide some conclusions.

1. The basis of A. Vvedensky's poetry is language-game.

2. Language-game acts as one of the "nonsense" realization, while at the same time the "author-text-reader" relationship specifies the game setting and forms the strategy of text establishment.

3. One of the brightest methods of language-game in linguistic and poetic space of Vvedensky is rhythmic and intonational repetition.

4. Violation of natural language norms in fictional world of author is aesthetically motivated.

\section{Conclusions}

Listed features of A. Vvedensky's language world view, if desired, can be easily multiplied, we can easily find other major components of language game, thanks to which we can observe how a new language able to be a medium between the world and people is attempting to be created. Scholarly sound combinations are meaningless, but they can always be freely interpreted, even if subjectively. Thus, it is appropriate to allow diverse subjective interpretations that do not stray away from the original text.

ACKNOWLEDGEMENTS: The work is performed according to the Russian Government Program of Competitive Growth of Kazan Federal University.

\section{REFERENCES}

BIDERKESEN D.; AGEEVA J.V.; SEVINC U. Military Vocabulary as a Special Element of a Language Lexical System. Jour of Adv Research in Dynamical \& Control Systems, v. 11, n. 08, p. 467-470, 2019. 
DRUSKIN, Y. S. Zvezda bessmyslicy. «Sborishche druzej, ostavlennyh sud'boyu» In: VEDENSKIJ, A. V.; LIPAVSKIJ, L.; DRUSKIN, Y. A.; HARMS, D.; OLEJNIKOV, N. «chinari» $\mathbf{v}$ tekstah, dokumentah i issledovaniyah. Moscow: Ladomir, 2000. v. 1, p. 846.

EROFEEVA, I. V.; GIMATOVA, L. I.; SERGEEVA, E. V. Modeling of the lexico-semantic field «intellect» in the Russian translation of Herman Hesse's novel «Steppenwolf». Modern Journal of Language Teaching Methods (MJLTM), v. 8, n. 9, p. 54-59, 2018.

GRIDINA, T.A. Associativnyj potencial slova i ego realizaciya v rechi. Yavlenie yazykovoj igry [Associative potential of word and its realization in speech. Language-game phenomenon]: dissertation of the candidate of philological sciences. Moscow, 1996. p. 566.

NIKOLINA, N. A.; AGEEVA, E. A. Yazykovaya igra v sovremennoj russkoj proze" // Russkij yazyk segodnya. Moscow, n. 1., p. 551-561, 2000.

SAFIN, I. C. H.; KOLOSOVA, E. I.; GIMRANOVA, T. A. Interpretation of an Epoch in the Novel the Big Green Tent by L. Ulitskaya: Linguistic-Cultural Analysis of Verbal Lexicon.

Tarih Kultur ve Sanat Arastirmalari Dergisi-Journal of History Culture and Art Research, v. 6, n. 5, p. 116-121, 2017.

SHTYRLINA, E. G.; ANTROPOVA, M. Y. Semantics of the artistic image of the moon in K. Balmont's poetry. Amazonia Investiga, v. 7, n. 13, p. 233-238, 2018.

SPIRIDONNOV, A. V.; KHABIBULLINA, E. V. Occasional derivation as a way of era language stylization in v. aksyonov's novel" voltairiens and voltairiennes. Journal of Language and Literature, v. 7, n. 1, p. 219-222, 2016.

STAROSTINA, O. V.; BOCHINA, T. G.; LARIONOVA, E. S. Archetype of water in the Silver Age poetry. In: INERNATIONAL MULTIDISCIPLINARYSCIENTIFIC CONFERENCE ON SOCIAL SCIENCES \& ARTS, 4., 2017. Proceedings [...]. SGEM, 2017. v. 2, p. 579-585.

VALIEVA YU. M. Igra v bessmyslicu [A game of nonsense]. 2016. Available: http://literary.ru/literary.ru/readme.php. Access: 10 dec. 2020.

WITTGENSTEIN, L. Filosofskie issledovaniya. Filosofskie raboty. Moscow: Gnozis, 1994. v. 1, p. 612

ZEMSKAYA E. A.; KITAJGORODSKAYA M. V.; ROZANOVA N. I. Yazykovaya igra" // Russkaya razgovornaya rech': Fonetika. Morfologiya. Leksika. ZHest. Moscow: Nauka, , 1983. p. 172-214. 


\section{How to reference this article}

AKHMETZYANOVA, L. M.; SHTYRLINA, E. G.; ZHURAVLEVA, Y. A. Regarding the issue of specificity of A.I. Vvedensky's language. Rev. EntreLínguas, Araraquara, v. 7, n. esp. 1, p. 173-183, fev. 2021. e-ISSN: 2447-3529. DOI: https://doi.org/10.29051/el.v7iEsp1.14886

Submitted: 28/10/2020

Required revisions: $19 / 12 / 2020$

Approved: 13/01/2021

Published: 28/02/2021 